\title{
MEETING SUSTAINABLE DEVELOPMENT GOALS - EXPERIENCE FROM THE LARGEST SHIPPING COMPANIES
}

\author{
Katarina Balić, Helena Ukić Boljat, \\ Gorana Jelić Mrčelić, Merica Slišković \\ University of Split (Croatia)
}

\begin{abstract}
The UN agenda for Sustainable Development underlines the importance of balanced and integrated environmental, economic and social development through 17 goals. The role of the shipping industry in achieving the sustainable goals is recognized and highlighted by UN. As shipping companies are one of the most important stakeholders in the global economy and maritime transport, sustainable goals must be integrated into their continued operations and development. This paper aims to analyze the commitment of the largest shipping companies to the Sustainable Development Goals (SDG). From their annual reports for 2019 and 2020, an analysis of the commitment to SDG was conducted. The analysis shows that the majority of the companies comply with the SDG and embed them in their daily business processes.

Keywords: maritime industry; shipping companies; ports; sustainable development goals; implementation
\end{abstract}

\section{Introduction}

In 2015, the European Commission adopted UN Sustainable Development Program to establish a framework for sustainable development. Sustainable Development Agenda 2030 "Transforming our world" was adopted at the UN Sustainable Development Summit. The Agenda emphasizes the importance of a balanced and integrated performance of sustainable development in three pillars: Economic, Environmental and Social. It sets out seventeen goals and $169 \operatorname{targets}^{1,2}$. The goals are presented in Figure 1.

Given that shipping companies are some of the important stakeholders in the global economy and maritime transport, it is important that their further development and business are based on sustainable development. To achieve the interest of shipping companies in including sustainable development goals in their business, UN Global Compact and KPMG International Cooperative (KPMG) they jointly devised the SDG industrial matrix. All companies have the same responsibility to 

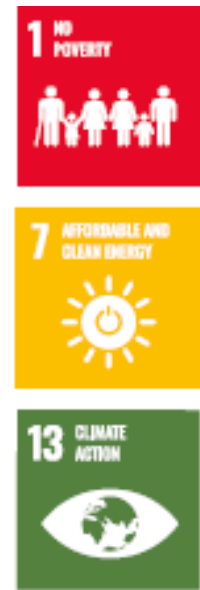
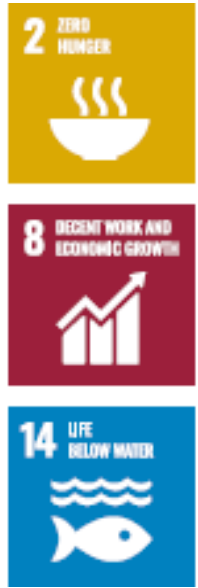

Figure 1. The Sustainable development goals ${ }^{3)}$
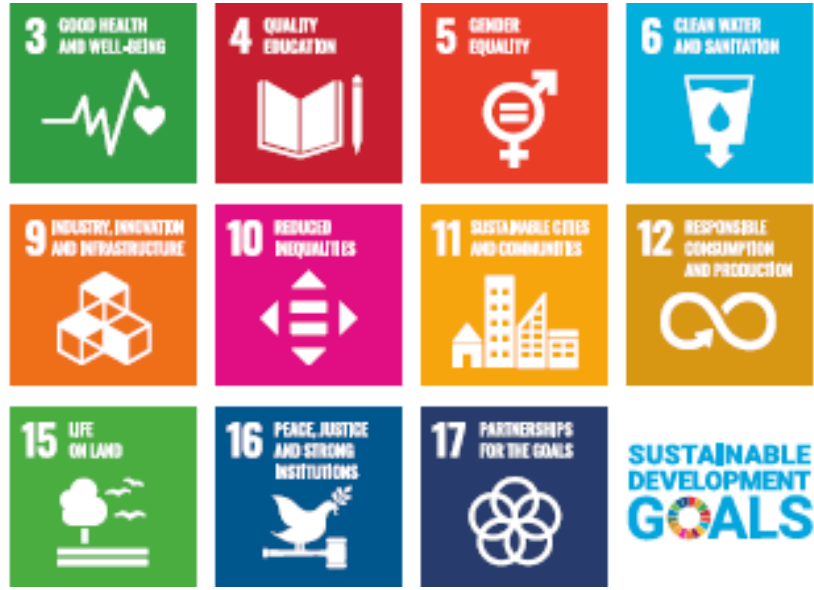

SUSTAINABLE DEVELOPMENT GQALS

comply with internationally relevant laws and to recognize fundamental human rights. The SDG industry matrix is built on these premises ${ }^{4)}$.

Ports are points of convergence between maritime and inland transport, and they should be able to respond to different challenges. Accordingly, their role and functions in the SDGs should also be taken into account.

Given the lack of research in this context and the first major research conducted in (Wang et al. 2020), it is important to observe to what extent and how many key stakeholders have started to consider and implement the SDG guidelines. On those grounds, the research question is whether major shipping companies consider the SDGs in their annual reports.

This paper aims to analyze the commitment of shipping industry and port sector to sustainable development goals. The commitment of shipping industry will be presented through an overview of the 10 largest shipping companies, while the commitment of the port sector will be presented through linkages of the five themes which are created within The World Ports Sustainability Program.

\section{Commitment of shipping industry to SDG}

Analyzing annual reports for 2019 and 2020 of 10 shipping companies: Maersk, COSCO, Mediterranean Shipping Company, CMA, CMG, Hapag Lloyd, ONE, Evergreen, Yang Ming, HMM, Pacific International Lines their commitment to the different SDGs were observed. Similar research, including 40 shipping companies is done in (Wang et al. 2020), but some differences in results were found. The differences have to been seen in light of some limitations because a larger number of companies is observed within (Wang et al. 2020), and the observed period is 2016-2019, while our analysis cover 2019 - 2020 period. 
The majority of the observed company have stated sustainable goals in their annual reports (Table 1.)

Table 1. Application of SDG within 10 shipping companies

\begin{tabular}{|l|c|c|c|c|c|c|c|c|c|c|c|c|c|c|c|c|c|}
\hline $\begin{array}{l}\text { Shipping } \\
\text { companies }\end{array}$ & 1. & 2. & 3. & 4. & 5. & 6. & 7. & 8. & 9. & 10. & 11. & 12. & 13. & 14. & 15. & 16. & 17. \\
\hline Maersk & & + & + & & + & & + & $+^{*}$ & $t^{*}$ & + & & $+^{*}$ & $+^{*}$ & + & & + & $+^{*}$ \\
\hline COSCO & $+^{*}$ & + & + & + & + & + & $+^{*}$ & $+^{*}$ & + & + & + & + & $+^{*}$ & $+^{*}$ & + & + & $+^{*}$ \\
\hline $\begin{array}{l}\text { Mediterranean } \\
\text { Shipping } \\
\text { Company }\end{array}$ & + & + & + & + & + & + & + & + & + & + & + & + & + & + & + & + & + \\
\hline CMA CGM & & & + & + & + & & + & + & + & + & & + & + & + & & & + \\
\hline Hapag_Lloyd & & & & + & & & & + & & & & & + & + & & + & + \\
\hline ONE & & & & + & + & & + & + & + & + & & + & + & + & & + & + \\
\hline Evergreen & & & + & + & + & & & + & & & & + & + & + & & & + \\
\hline Yang Ming & & & + & + & + & & & + & & & + & + & + & + & & + & + \\
\hline HMM & & & + & & & & & + & & & & & & + & & & \\
\hline $\begin{array}{l}\text { Pacific } \\
\text { International } \\
\text { Lines }\end{array}$ & & & & & & & & & & & & & & & & & \\
\hline
\end{tabular}

*primarySDGs

Company Maersk published its first sustainability report in 2014 and incorporated SDG in 2016. A. P. Moller - Maersk's introduces all $17 \mathrm{SDGs}^{5,6)}$. From the sustainability report from 2019, the company Maersk has provided a table with all company activities through sustainability goals. The stated goals are listed in Table 1. Five SDGs are prioritized: 8, 9, 12,13, and 17. For example, their work on food losses contributes directly to Goal 12 , specifically sub-goal 12.3 on food losses. Their work on responsible ship recycling contributes to Goal 8 on decent work and economic growth. The decarbonization of logistics is an important contribution to Goal 13 on climate action, and progress on trade contributes to many of the Goals' sub-goals, particularly Goals 8 and $9^{6}$.

Company Cosco published its first sustainability report in 2008 and incorporated SDG in 2017. COSCO SHIPPING has ranked the SDGs in terms of criticality and importance and accordingly divided them into primary SDG and relevant SDGs. The primary SDG are 1, 7, 8, 13, 14 and 17. They concentrate resources and expertise to achieve the primary SDG to contribute to sustainable development ${ }^{7)}$.

Mediterranean Shipping Company published its first sustainability report in 2016, which includes sustainable development goals. As part of the international shipping sector, Mediterranean Shipping Company contributes to and impacts all SDG ${ }^{8,9)}$. 
In 2018, CMA CGM incorporated all 17 SDG within its sustainable development policy ${ }^{10)}$. No information on the company's previous sustainable development goals is available on its website. CMA CMG company has three pillars of development policy. Acting for people includes SDG 3, 4, 5, 8, 10 and 17. Acting for the Planet includes SDG 3, 7, 12, 13 and 14, and Acting for Responsible Business includes SDG 9 and $12^{10)}$.

Company Hapag-Lloyd published its first Sustainability Report in 2017 and included SDG in 2018. In its 2019 Sustainability Report, Hapag-Lloyd analyzed the company's positive contributions to SDG. It highlighted its contribution to 6 goals: 4, 8, 13, 14, 16 and $17^{11)}$.

Ocean Network Express (ONE) published its first sustainability report in 2018 and embraced SDG in 2020. As a corporate member of UNGC Singapore, ONE recognizes the importance of the 17 global SDG. In the 2019 report $^{12)}, 11$ goals were highlighted.

Evergreen published its first Responsibility Report in 2014 and incorporated the Sustainable Development Goals in 2016. In 2018, Evergreeen Marine began incorporating SDG into its business. The 2019 report $^{13}$ highlighted 8 goals in particular.

Yang Ming issued its first responsibility report in 2012, while it took up SDG in 2020. Yang Ming in its 2019 Sustainability Report covered 14 topics: Operation Performance, Sustainable Development strategy, Energy Management,Greenhouse Gas (greenhouse gas emissions), employee-employer relationship, occupational health and safety, risk management, employee welfare, information security, customer service management, Career Development, Waste Water and Garbage Management and Green equipment, including the following sustainable development goals: 3, 5, 4, 8, 11, 12, 13, 14, 16, 17 (Yang 2020).

The SDG are embedded in 2019 Hyundai Merchant Marine Sustainability Report. It is necessary to emphasize that they are not available on the website reports from the previous year. As a member of the global civil society, HMM wants to participate in solving the future environmental and social problems of humanity by contributing to the fulfilment of SDG. HMM considers occupational health and safety as a fundamental material issue. In this context, they promote the safety of people, the environment and shipping, which is in line with SDG 3, 8 and $14^{14)}$.

On the website of Pacific International Lines, the company emphasizes its commitment to the goals, it has long-term impact on the organization, stakeholders, society and the environment, but no report on sustainability and linkage with the Sustainable Development Goals is available.

From the above analysis of shipping companies, it can be concluded that some companies have included all of the Sustainable Development Goals in their reports, while some have included only some of the goals.

Furthermore, the results presented in (Wang et al. 2020), conducted by assigning each paragraph of the sustainability reports to the SDGs, show that the main contribution of the maritime industry is associated with SDG 8, SDG 9 and SDG 11. 
On the other hand, our results, which involved searching for the commitment to the SDGs in the sustainability report, show that most companies associate their business with SDG 8, SDG 14, SDG 13 and SDG 14.

Some companies have explicitly stated priority goals. For example, the Danish shipping company has classified the sustainable development goals into three categories: 'lowest', 'moderate' and 'highest' impact on shipping ${ }^{15)}$, which can serve as a good example for other shipping companies. If the SDGs are to be achieved, each industry sector must prioritize its activities and focus on the goals on which they have the greatest impact.

\section{Commitment of port industry to SDG}

The International Association of Ports and Harbors launched a World Ports Sustainability Program (WPSP) in 2017. Since 2018, WSPS has been creating and maintaining a global database of sustainable development projects related to the port sector. Worldwide, 71 ports with 120 projects are included in this database and can serve as best practice examples ${ }^{3)}$.

The program recognizes the importance of the 17 SDGs to serve as guiding principles for sustainable port development. The WPSP organizes the individual SDGs into the five themes of ${ }^{3)}$ :

1) Climate and Energy (energy efficiency, circular economy, bio-based economy, renewable energy, $\mathrm{CO} 2$ and infrastructure, incentives for clean ships, use of alternative transport fuels).

2) Community outreach and port-city dialog (stakeholder management, sustainability reporting, community outreach, city-port relations, employment, education, spatial planning, nature in the port, port culture, externalities of port operations)

3) Governance and ethics (transparency, integrity, equal rights and opportunities, fair trade, anti-corruption, responsible supply chains)

4) Resilient infrastructure (port planning and design, public-private partnerships, financing, digitalization and automation, climate resilience, working with nature, ecosystem management)

5) Safety and Security (cybersecurity, critical infrastructure protection, ISPS, nautical safety, labor safety, responsible care).

Figure 2 shows the link between the five WPSP themes and the SDG. Individual goals cover multiple themes. For example, Goal 8: Decent Work and Economic Growth is a part of four themes, such as: Climate and Energy, Community Outreach and Port City Dialog, Resilient Infrastructure, and Safety and Security. Goal 11: Sustainable Cities and Communities and Goal 12: Responsible Consumption and Production are also part of the four themes such as: Climate and Energy, Community Outreach and Port City Dialog, Governance and Ethics, and Safety and Security.

It can be concluded that all SDG are applicable to sustainable development of the ports. 


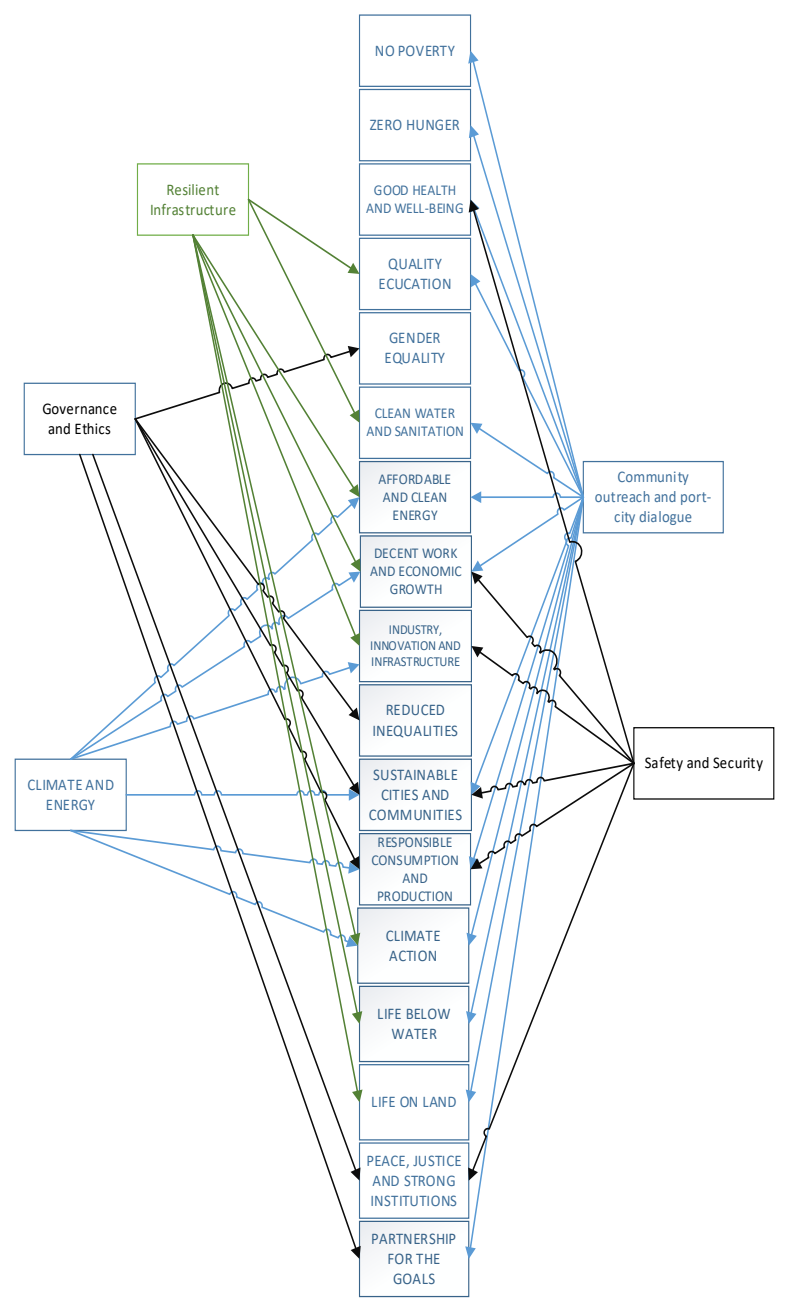

Figure 2. The link between the five WPSP themes and SDG

\section{Conclusions}

As part of global trade, the ports and shipping companies must consider the sustainable pillars in further development, i.e. they should be committed to SDG. The 17 SDG serve as guiding principles for the sustainable development of shipping and ports.

The major contribution of the maritime industry to SDGs can be reflected through SDG 14 (Life Below Water). It is important to stress that the contribution of the maritime industry can and must go far beyond SDG 14. 
The analysis of the websites of the ten largest shipping companies reveals that the majority of observed companies publish sustainability reports. Only Pacific International Lines has never published a sustainability report despite the fact that the company emphasizes its commitment to SDG.

The analysis shows that the majority of the shipping companies embed SDGs in their daily business processes. The International Association of Ports and Harbors has identified five strategic themes that cover all SDG and launched a WPSP in 2017. The program recognizes the importance of the 17 SDGs to serve as guiding principles for sustainable port development.

\section{NOTES}

1. DNV·GL, Sustainable development goals: Exploring maritime opportunities, United Kingdom, Available at: www.dnvgl.co.uk, Accessed: 21 April 2021.

2. United Nations, Transforming our world:the 2030 Agenda for sustainable development, Available at: https://sdgs.un.org/goals, Accessed: 7 April 2021.

3. WPSP - World port sustainability program. Available from: https:// sustainableworldports.org/wp-content/uploads/WORLD-PORTSSUSTAINABILITY-REPORT-2020-FIN.pdf, Accessed: 21 April 2021.

4. United Nations Global Impact,SDG IndustryMatrix, Transportation (2016), Available at:https://www.unglobalcompact.org/library/3111, Accessed: 7 April 2021.

5. A. P. Moller-Maersk, Sustainability Report (2020), Copenhagen K. Available from: www.maersk.com, Accessed: 7 April 2021.

6. A. P. Moller-Maersk. Sustainability Report (2019), Copenhagen K. Available from: www.maersk.com, Accessed: 7 April 2021.

7. COSCO, Sustainability report (2019), Shanghai, China, Available at: http:// en.coscoshipping.com/Accessed: 20 April 2021.

8. MSC - Mediterranean Shipping Company, Sustainability Report (2019), Geneva, Switzer-land, Available at: www.msc.com, Accessed: 7 April 2021.

9. MSC- Mediterranean Shipping Company, Integration of the SDGSinto the activities of a large shipping company (2019), Geneva, Switzer-land, Available from: www.msc.com, Accessed: 7 April 2021.

10. CMA-CGM, Sustainable development at a glance, Acting for people, planet and responsible trade (2019), France, Available at: www.cma-cgm.com, Accessed: 7 April 2021.

11. Hapag-Lyold, Sustainability report, (2019), Hamburg, Available at: www.hapaglloyd.com, Accessed: 7 April 2021.

12. ONE- Ocean Network Express, Sustainability Report (2020), Singapore, Available at: www.one-line.com, Accessed: 7 April 2021. 
13. EVERGREEN MARINE CORP., Corporate Social Responsibiliy Report, Dedicated to Enriching Your Life (2019), Taiwan, Available at: www.evergreenmarine.com/, Accessed: 7 April 2021

14. HMM - Hyundai Merchant Marine Co., Sustainability report, (2019), Yulgok-ro, Jongno-gu, Seoul, Republic of Korea, Available at:www.hmm21.com, Accessed: 7 April 2021.

15. Danish Shipping, Danish Shipping and the Sustainable Development Goals (2018), Danish, Available at: https://www.danishshipping.dk/en/policy/ sustainable-development-goals, Accessed: 21 April 2021.

\section{REFERENCES}

Yang, M., 2020. Corporate Social Responsibility Report. Keelung, Taiwan, Available from: www.yangming.com, Accessed: 20 April 2021.

Wang, X., Yuen, KF., Wong, YD. \& X. Li, K., 2020. How can the maritime industry meet Sustainable Development Goals? Ananalysis of sustainability reports from the social entrepreneurship perspective, Transportation Research Part D. Transport and Environment. 78. Available from: https:// doi.org/10.1016/j.trd.2019.11.002.

Katarina Balić

University of Split Split, Croatia

E-mail: katarina.balic@unist.hr

Helena Ukić Boljat https://orcid.org/0000-0003-2109-9516

Faculty of Maritime Studies University of Split Split, Croatia E-mail: hukic@pfst.hr

Gorana Jelić Mrčelić https://orcid.org/0000-0002-6424-2215

Faculty of Maritime Studies University of Split Split, Croatia

E-mail: gorana.jelic@pfst.hr

Merica Slišković https://orcid.org/0000-0003-3951-9822

Faculty of Maritime Studies University of Split Split, Croatia E-mail: merica@pfst.hr 